\title{
Global chronostratigraphical correlation table for the last 2.7 million years, version 2019 QI-500
}

\author{
K.M. Cohen ${ }^{1,3} \&$ P.L. Gibbard ${ }^{2,3}$ \\ ${ }^{1}$ Dept. of Physical Geography, Faculty of Geosciences, Utrecht University, P.O.box 80.115, 3508 TC Utrecht, The Netherlands.. \\ 2 Scott Polar Research Institute, University of Cambridge, Lensfield Road, Cambridge CB2 1ER, England, U.K.. \\ ${ }^{3}$ IUGS International Commission on Stratigraphy
}

Abstract: 132 words | Main Text: 6637 words | References: 3576 words | 2 figures | No Tables

\begin{abstract}
A substantially updated version of the correlation table showing chronostratigraphical subdivisions of late Cenozoic geological time, spanning the last 2.7 million years is presented. It provides scientists, students, professionals and the general public with a ready reference to stratigraphical terms and schemes in use in different areas for similar periods. The updates comprised the status of Quaternary chronostratigraphic subdivision, the combined age-modelled geomagnetic and isotope records from ocean drilling records, and revised regional correlation schemes, notably for eastern Europe. The paper describes the chart in its 2019 QI-500 form and contains sections on its types of usage and formal subdivision status, besides reference and description of the contents of the various columns. The paper also describes and discusses the resolution of correlations in younger and older parts of the last 2.7 Ma.
\end{abstract}

\section{Keywords}

Quaternary; Stratigraphy; Geological Record; Correlation

\section{Introduction}

The Global Chronostratigraphical Correlation Table for the Last 2.7 Ma is a chart initiated by Gibbard et al. (2004, 2005) and Gibbard \& Cohen (2008), as output of work for Quaternary stratigraphic commissions of International Union of Quaternary Research (INQUA - SACCOM) and International Commission on Stratigraphy (ICS) (Subcommission on Quaternary Stratigraphy: SQS). Every few years, incremental updates to the chart (Cohen \& Gibbard, 2010; 2016) have appeared online on the websites of these commissions and have been distributed as handouts at conferences.

The chart covers the last 2.7 Ma, has global coverage and resolves to the nearest 5,000 years in its graphics. The chart communicates that because different regions hosted different Quaternary 
environments, regional schemes differ between countries and between land and sea. The chart is designed to provide a ready reference to stratigraphical terms that are in use in different areas and environments but apply to the same time periods. The many regional terms it contains, makes it useful as an aide memoire for scientists and students needing to look up terms encountered in the literature on parts of the global Quaternary record with which one is not yet familiar. The overview that it provides, makes it useful as an infographic to show professionals and general public alike the general structure and global communality of the Quaternary geological record. These two types of usage explain why the chart (and derivates) has seen wide usage in text books, as lecture materials and so on.

For this special issue of Quaternary International (QI-500) and the 2019 INQUA Congress in Dublin, a major update of the correlation table is produced (Fig. 1), as well as of its documentation and referencing. The updates cover the Holocene and Pleistocene chronostratigraphic subdivision (Walker et al. 2012; 2018; Gibbard \& Head, 2015), the combined age-modelled geomagnetic and isotope records from ocean drilling records (Channell et al., 2016) and regional correlation schemes, notably for eastern Europe. However, the chart retained previously featured main elements including the marine isotope stages (Lisiecki \& Raymo 2005), the Antarctic ice-core record (EPICA Dome-C) and the Chinese Loess terrestrial sequence (Ding et al., 2005). Headers above and grouping indicators below the chart columns communicate their nature, while labels along the plotted records communicate depths besides age. An inset table for the last 50,000 years at higher resolution is also included (Fig. 2).

This paper provides the background to the schemes and records in the correlation table. It is a completely revised edition of Gibbard \& Cohen (2008) and 2010-2016 smaller amendments. Original section headings are retained, while a new section on correlation resolution and accuracy has been added. To the uses of the chart, the description in this paper importantly adds the reference function of the chart that is needed to cite individual records and schemes displayed on the chart, and a helpful entry point when reading on Quaternary stratigraphic matters.

\section{Formal subdivisions}

The timescale adopted on the chart follows the internationally-recognised formal chronostratigraphical /geochronological subdivisions of time: the Phanerozoic Eonathem/Eon; the Cenozoic Erathem/Era; the Quaternary System/Period; the Pleistocene and Holocene Series/Epoch, each with subseries divisions, down to the Stage/Age formal level that is the building block unit of the IUGS-ICS international chronostratigraphic chart (Cohen et al., 2013: updated in 2018-08). The Quaternary currently includes the Gelasian and Calabrian as Stage/Ages in the Lower Pleistocene Subseries/Subepoch, unnamed younger Stages/Ages in the Middle and Late Pleistocene, and at its top three recently (Walker et al., 2018) introduced Stages/Ages Greenlandian, Northgrippian and Meghalayan to allow the definition of subseries/subepochs for the Holocene (see below). 
Subdivision at Series- and Stage-level in the Quaternary is based on the recognition of repeated major global climatic oscillations throughout its stratigraphical record, to distinguish especially the younger cycles individually, and to practically group these climatic variations in the less completely preserved and less accurately resolvable older Quaternary. Variations in Earth's rotation axis, obliquity and precession, and eccentricity of its solar orbit, have caused cyclic variations in solar irradiation and thus Earth's atmospheric energy budgets and climate (Imbrie \& Imbrie, 1980). This has repeatedly triggered glacials that were strong and repetitive enough to warrant climato-stratigraphic subdivision of the youngest few million years - the concept behind Marine Isotope Stages as recognised in the Pleistocene and Pliocene (see section: Oceanic Drilling record). Over successive cycles, however, the geological records show considerable variation in rates of climate change and minima and maxima reached. In the last 1 million years glacial cycles - past a transient period called the Mid-Pleistocene Revolution - had a periodicity of c. $100 \mathrm{ka}$ and the glacial minima were profound (associated to ice ages in the classic notion of workers such as Agassiz in 1847 and Penck \& Brückner in 1909), while for million years before the cyclicity was $c .41 \mathrm{ka}$ in duration the glacial minima during which were less severe (of shorter duration and mostly milder, though some Early Pleistocene cycles show relatively deep minima as well). Dramatic changes in the orbital parameters can safely be excluded and instead the shift in frequency of glacial cycles in the Quaternary record shows that the way the Earth modulates and amplifies orbital forcing progressively evolved. While the various schemes in the correlation table are based on geological study of regionally differing palaeoenvironments, and hence are distinguished using different division criteria, the alignments in the correlation table as a whole emphasise the shared, dominant glacial-interglacial cyclicity that underpins Quaternary chronostratigraphy.

The formal division of the Quaternary is the responsibility of the International Union of Geological Science's (IUGS) International Commission on Stratigraphy (ICS), the Subcommission on Quaternary Stratigraphy (SQS), in partnership with the International Union for Quaternary Research's (INQUA) Commission on Stratigraphy and Chronology (SACCOM). Series, and thereby systems, are formallydefined based on Global Stratotype Section and Points (GSSP) that are tied to the base of stages. Two such GSSPs divide the Quaternary System into the Holocene and Pleistocene Series, and further GSSPs function to subdivide Series into multiple Stages. Intermediate to the Series and Stage units, subdivision into Subseries (Subepochs) are in the process of being formalised. For the Holocene, Subseries/Subepochs have been ratified (see below), while for the Pleistocene they are under consideration (status January 2019).

The base of the Pleistocene (Gibbard \& Head, 2010; Gibbard et al., 2010) is defined by the GSSP at Monte San Nicola in southern Italy, marking the base of the Gelasian Stage (Rio et al., 1994, 1998). 
The Gelasian GSSP at 2.58 Ma replaces the pre-2009 Pleistocene base GSSP ( $\sim 1.8 \mathrm{Ma}$, defined at Vrica, southern Italy). The $\sim 1.8 \mathrm{Ma}$ GSSP is retained to define the base of the Calabrian Stage. The chart mentions that the base of the Pleistocene was administratively lowered in 2009, an outcome of 60 years of discussion (Head \& Gibbard 2015. See also: Ogg \& Pillans, 2008; Head et al., 2008; Lourens, 2008; Gibbard \& Head, 2009a,b; Gibbard, 2010; Gibbard et al., 2010). Since 1948 there has been a consensus that the basal boundary of the Quaternary/Pleistocene should be placed at the first evidence of climatic cooling of ice-age magnitude. This was the original basis for placing the boundary at $\sim 1.8$ Ma in marine sediments at Vrica in Calabria, in Italy (Aguirre \& Pasini, 1985). Since that time, it became known that a major cooling occurred earlier, at c. 2.55 million years (Cita, 2008), and that even earlier cooling events featured in the Pliocene. The closure of Central American Seaways between the Pacific and Atlantic Oceans around 3.2 Ma, significantly restructured oceanic and atmospheric circulation on the Northern Hemisphere, causing increased high-latitude precipitation, raised ice-sheet inception potential, freshening of the Arctic Ocean and increased sea-ice cover amplifying cooling through albedo feedbacks, especially during insolation minima (Bartoli et al., 2005; Lunt et al., 2007; Sarnthein et al., 2009). By 2.7 Ma this restructuring shows a southward shift of ocean currents, and polar atmospheric circulation, observed as a drop in sea surface temperature (Hennissen et al., 2014; 2015), believed to explain the concurrent palaeoenvironmental transitions observed on land, establishing the glacial-interglacial oscillating climate mode associated with the Quaternary.. Since its definition at 1.8 Ma, there had been strong pressure for the basal Quaternary / Pleistocene boundary to be moved downwards better to reflect the initiation of major global cooling (Pillans \& Naish 2004; Gibbard et al., 2005; Bowen \& Gibbard, 2007; Cita \& Pillans, 2010), effectively corresponding to the Gauss / Matuyama magnetic Chron boundary (e.g. Partridge, 1997; Suc et al., 1997; Channell et al., 2016).

The younger part of the Pleistocene on the ICS geological time scale comprises two more named stages that have yet to be defined formally. Common placeholder labels for these stages are Middle Pleistocene and Late Pleistocene, because of their correspondence with Subseries. In the early 1990s, the INQUA Commission on Stratigraphy/ICS Working Group on Major Subdivision of the Pleistocene agreed to place the base of the Middle Pleistocene at the Brunhes / Matuyama magnetic polarity reversal (Richmond, 1996). This chron boundary occurs about midway through a climatic transition towards longer and more severe glacials - the 'Middle Pleistocene revolution' (see below) - that is another reason to divide the Middle from the Early Pleistocene (Head \& Gibbard, 2005; 2015; Head et al., 2008). A stratotype locality has been identified as the outcome of work by an ICS-SQS Working Group (Head et al., 2008; Head \& Gibbard, 2015), a GSSP proposal in the marine section exposed on the Chiba peninsula SW of Tokyo, Japan is currently being considered, while an auxiliary section in the Mediterranean is foreseen. This will mark the base of the Middle Pleistocene Subseries/subepoch, terminating the Early Pleistocene stages. 
The base of the Late Pleistocene is placed by historical precedent at that of the Last Interglacial, shortly following what is defined as Termination II in deep (ocean floor) and shallow (coral reef) marine isotope records (e.g. Siddall et al., 2003; Medina-Elizalde, 2013), and broadly coinciding with the base of the regional Eemian Stage in Western Europe (Zagwijn, 1992; Kukla et al. 2002; Gibbard, 2003; Litt \& Gibbard, 2008) and/or the wider North Atlantic (Iberian margin: Sanchez-Goñi et al., 1999; Shackleton et al., 2003; Greenland: NEEM-members 2013). Again, a most-suitable stratotype locality to host a GSSP has yet to be identified, with the SQS soliciting candidate localities, whether in an Antarctic ice core record, in a speleothem, a marine or terrestrial sedimentary record. Accurate agecontrol and event-scale stratigraphic correlation within Termination II and the Last Interglacial (i.e. at a higher resolution than in the presented chart) is important to obtain a second measure on the lag times of slower components of the Earth's climate system over terminations, in circumstances other than that of Termination I and the Holocene. Establishing the precise lag time is an important current research goal, tying global sea-level, ice-mass and crustal glacio-hydroisostasy studies for different interglacials to regional climatic variation, oceanography and palaeomagnetics (e.g. Shackleton et al., 2003; Lourens, 2004; Lambeck et al., 2006; Dutton \& Lambeck, 2012; Dutton et al. 2015; Long et al. 2016; Barlow et al. 2018).

The Holocene chronometrically is generally regarded as having begun 10,000 radiocarbon years before $1950 \mathrm{CE}$ (the zero datum of the radiocarbon timescale). Chronostratigraphically, it is defined to have begun at 11,703 $\pm 99(\sim 2 \sigma)$ calendar years before $2000 \mathrm{CE}$, recorded at $1492.45 \mathrm{~m}$ depth in the NorthGRIP ice core of the Greenland Ice-Core Project (NGRIP: Rasmussen et al., 2006; Hoek, 2008). The base of the Holocene has been defined as a Global Stratotype Section and Point (GSSP) in the NGRIP ice core (Walker et al., 2008; 2009). Auxiliary stratotypes are also defined, for example, in an annually-laminated lake sequence in western Germany (Litt et al., 2001). The Holocene Series has recently been divided into three named stages (ratification July 2018). This step was taken to help defining and formalising (Walker et al., 2012) the Early, Middle and Late Holocene Subseries/Subepochs and have their bases marked with GSSPs. In addition to the base Holocene GSSP (base Greenlandian), these are the base Northgrippian GSSP in the same NGRIP core with an annual layer count age of $8236 \pm 47(\sim 2 \sigma)$ yr before $2000 \mathrm{CE}$ (Vinther et al., 2006; Walker et al., 2008), and the base Meghalayan with a GSSP in a speleothem from Mawmluh Cave, Meghalaya, India, with an associated radiometric age of $4250 \mathrm{yr}$ before $2000 \mathrm{CE}$ (Walker et al., 2018).

The 'Anthropocene' is not yet a formalised chronostratigraphic unit and for that reason is not yet shown in Fig. 1, although a mid-20 $0^{\text {th }}$ Century basal date onset is nowadays entertained by the ICS- SQS working group on this (Waters et al., 2016; Zalasiewicz et al., 2017) and a sedimentary section is being sought to chronostratigraphically define a base Anthropocene using a GSSP. In anticipation, but also to 
allow the correct expression of the Holocene subseries ages to their significant digit from the present, the updated chart from this version onwards specifies $1950 \mathrm{CE}$ as the calendar age of $0 \mathrm{Ma}$. Not coincidentally when it comes to the selected year (the link being the beginning of nuclear weapons testing), this is similar to what the radiocarbon dating community once decided to do (Stuiver \& Polach, 1977): fixing 'the present' to a calendar date. If such is accepted, the event will be marked by a Global Standard Stratigraphic Age (GSSA). By convention, uncalibrated ${ }^{14} \mathrm{C}$ ages prior to $1950 \mathrm{CE}$ are reported as dates in years 'BP' (i.e. Before Present), with the recommendation that this unit is used only for dates obtained with radiocarbon dating (Van der Plicht \& Hogg, 2006). This restriction triggered the ice-core community to introduce 'B2K' tied to $2000 \mathrm{CE}$ (Wolff, 2008) for their records. The chart displays the base Holocene Series/Epoch as $0.0117 \mathrm{Ma}$ (rounding 11,650 before $1950 \mathrm{CE}$ ), as does the ICS International Chronostratigraphical Chart (v. 2018-08). The Middle and Late Holocene Subseries/Subepoch onset ages are 0.0082 and $0.0042 \mathrm{Ma}$.

\section{Oceanic drilling record: global-distributed stacks as correlation targets}

Isotope studies from fossil foraminifera preserved in the bottom sediments of the world's oceans (stable oxygen isotope fractionation, $\delta^{18} \mathrm{O}$ ) have indicated that during the last $2.6 \mathrm{Ma}$ as many as 52 cold and interspersed warm climate periods occurred, often referred to as glacials and interglacials (e.g. Suggate, 1965). Furthermore, geomagnetic studies on the same deep marine cores have revealed alternating periods of normal and reversed inclination, and brief excursions of the magnetic poles marking times of relative low field strength (relative palaeointensity, RPI; e.g. Channell et al. 1997). These two-types of proxy-records are available from for an increasing globally distributed network of ocean floor drilling sites.

So-called 'stacks' of these proxy data are created by combining and cross-correlating high-resolution data series from those sites that span long time periods at sufficiently high enough sampling resolution (e.g. Lisiecki \& Raymo, 2005; Channell et al., 2009). These are produced to summarise the common signal in the global datasets and to establish calibrated age models, by tuning the signals to the beat of Milankovitch orbital cyclicities (Martinson et al., 1987). The stacks also serve as correlation targets for less long and/or less continuous Quaternary sequences from the other sedimentary environments on Earth: terrestrial continental and shallow marine continental shelf records. That evidence is typically incomplete and more regionally variable, meaning that terrestrial glacial-interglacial stratigraphies must refer to the ocean record for a global chronological foundation (see also the section on Correlation resolution).

The inventory of geomagnetic chrons, subchrons and excursions on the chart, is taken from the compilation of Lai \& Channell (2007: their Tables 2 and 3). Geomagnetic excursions and reversals occur at times of low magnetic field intensity. Excursion and reversal ages are updated after Channell 
et al. (2009; 2016), who produced a stacked palaeointensity record established on deep-sea core evidence from 13 locations around the world (2009: PISO-1500), extended with North Atlantic data from 4 cores (NARPI-2200). For the period beyond 2.2 Ma, a single North Atlantic core record is available (Channell et al., 2016: IODP Site U1308), which newly identified the Porcupine excursion featured at the very base of the chart. Independent age-control for the various magnetic events comes primarily from ${ }^{40} \mathrm{Ar} /{ }^{39} \mathrm{Ar}$ dating of volcanic lava. Such age-estimates in isolation, however, have a lower precision than combined data on palaeomagnetics and oxygen isotope stratigraphy from deep sea drilling offers (Shackleton et al., 1990; Lourens et al., 2004; Channell et al., 2016). Naming of subchrons and excursions is after geographical locations where they were first recognised, some volcanic on land (e.g. Olduvai; subchron within the Early Pleistocene; c 1.975-1.750 Ma), some marine offshore (e.g. Blake; excursion within the Late Pleistocene, c. $0.121 \mathrm{Ma}$ ). The palaeomagnetic chrons are, by convention, named after pioneer scientists in palaeomagnetism.

The deep-sea based, climatically-defined marine isotope record shown on the chart, is taken from oxygen isotope data retrieved from deep-ocean cores from 57 locations around the world (the so-called LR04 stack, compiled and age-tuned by Lisiecki \& Raymo, 2005), and expressed as $\delta^{18} \mathrm{O}$ (the ratio of ${ }^{18} \mathrm{O}$ versus ${ }^{16} \mathrm{O}$ divided by a modern-day standard, in \%o). Shifts in this ratio are a measure of global ice-volume, which is dependent on global temperature and which determines global sea-level. The data present here are those obtained from tests of fossil benthonic (ocean-floor dwelling) foraminifera, corrected for interspecies fractionation differences. Independent age-control for the various oxygenisotope events, in the Middle and Late Pleistocene comes primarily from U/Th dating of such signals in speleothems in monsoon affected parts of the world and coral reefs of the tropical seas. These ages are transferred to the ocean foraminiferal and Antarctic ice-core records by cross-correlation. In the youngest c. 40.000 years, ${ }^{14} \mathrm{C}$ dating, cross-correlation to annual-layered sedimentary records (Greenland ice core, varved lakes) and calibration to tree-ring stacks (dendrochronology, biological record) provides independent age-control. In the Early Pleistocene and beyond, independent ageestimates for volcanic event markers and aforementioned palaeomagnetic events are means of further validating and optimising astronomically-tuned ages (Lourens et al., 2004; Lisiecki \& Raymo, 2005; Suganuma et al., 2015).

The marine oxygen isotope record, and equally the terrestrial records featured on the chart, show the time between c. 1.2 and 0.5 Ma (Early-Middle Pleistocene Transition; Head \& Gibbard, 2005, 2015) to have been a transitional period during which low-amplitude 41-ka obliquity-forced climate cycles of the earlier Pleistocene were replaced progressively by high-amplitude 100-ka cycles. The first part of the period is labelled the Mid-Pleistocene Revolution, the last phase of transition the Mid-Brunhes Event (Lisiecki, 2004). Orbital and non-orbital climate forcing, palaeoceanography, stable isotopes, organic geochemistry, marine micropalaeontology, glacial history, loess-palaeosol sequences, pollen 
analysis, large and small mammal palaeoecology and stratigraphy, and human evolution provide a series of discrete events identified from Marine Isotope Stage (MIS) 36 (c. 1.2 Ma) to MIS 13 (c. 540$460 \mathrm{Ma}$ ). The later cycles are indicative of slow ice build-up and subsequent rapid melting, and imply a strongly non-linear forced climate system compared to before, accompanied by substantially increased global ice volume during glacials after $940 \mathrm{ka}$. Of these, the cold maximum of MIS 22 (c. 880-870 ka) is the most profound. The shift towards longer-stronger ice ages that took place during the Quaternary, is to be considered the outcome of marked changes in the sensitivities and responses to the orbital forcing of multiple other elements in the earth system (i.e. not a change in the ice part of the system alone). The changes of the Early-Middle Pleistocene Transition affected the cryosphere, hydrosphere, biosphere and atmosphere, over land and over the oceans, changing the heat distribution, water cycle and carbon cycle, arguably even stronger than they did at the onset of the Pleistocene. They lead to increased severity and duration of cold stages, including changed overturning modes in the ocean (e.g. Lisiecki, 2014) and had a profound effect on the biota and the physical landscape, especially on the continents of the Northern Hemisphere (Head \& Gibbard, 2005; 2015).

The table includes the LR04 calibrated ages for the last seven major glacial terminations, and a standard scheme of numbering recognized interglacial (odd) and glacial (even) Marine Isotope Stages (MIS; Shackleton, 1969; Broecker \& van Donk, 1970; Railsback et al. 2015). The Penultimate and Last Glacial Maximum are abbreviated as PGM and LGM and are the cold maxima within MIS 6 and MIS 2 respectively. The use of these latter terms in the global sense, e.g. when deriving ice volumes from oceanic oxygen isotope records and sea-level low stand studies (e.g. Peltier \& Fairbanks, 2006; Carlson \& Clark, 2012), differs from that from region to region in connection to ice-margin mapping and dating (the farthest advance within the last glacial being the maximum advance). The global LGM and PGM center around the moments at which the globally-aggregated land ice volume reached a maximum within the last and penultimate glacial cycle. Last-glacial maximum ice advances differ in timing from region to region, between sectors and lobes of the same ice sheets, and between valley glaciers in the same mountain ranges (e.g. Hughes \& Gibbard, 2015), and do not necessarily coincide with the LGM as labeled along deep marine benthic foraminiferal $\delta^{18} \mathrm{O}$ records. This also explains our placement of the LGM global ice volume maximum and last sea-level low stand in the high-resolution inset chart of Fig. 2.

Planktonic foraminifera and calcareous nannoplankton provide an alternative biostratigraphical means of subdivision of marine sediments. The micropalaeontological zonation is taken from Berggren et al. (1995). In the Mediterranean region, especially in southern Italy, 'standard stages' have been defined, that is units that divide Quaternary time into portions of approximately the same duration as those in the pre-Quaternary time (i.e. Paleogene, Neogene). Their definition is based principally on faunal and protist biostratigraphy, with renewed multidisciplinary investigation in more recent years. The Italian 
shallow marine stages depicted here are derived from Van Couvering (1997) and modified by Cita et al. (2006) (cf. also Cita \& Pillans, 2010). See also the section on formal subdivisions above.

\section{Major continental records: Antarctic ice, Chinese loess, Lake Baikal}

Two plots of isotope measurements from Antarctic ice-cores are shown. The first is the 420-kyr-long plot from the Vostok core and shows atmospheric $\delta^{18} \mathrm{O}$ (Petit et al., 1999), determined from gas bubbles in the ice. This atmospheric $\delta^{18} \mathrm{O}$ is inversely related to $\delta^{18} \mathrm{O}$ measurements from seawater and therefore is a measure of ice-volume. It can also be used to separate ice volume and deep-water temperature effects in benthic foraminiferal $\delta^{18} \mathrm{O}$ measurements. The deuterium measurements $(\delta \mathrm{D})$ for the last $800 \mathrm{ka}$ are from the 3.2-km-deep EDC core in Dome C (EPICA community members, 2004; Jouzel et al., 2007). They come from samples of the ice itself and give a direct indication of Antarctic surface palaeotemperature.

For the Chinese loess deposits the chart shows the sequence of palaeosols (units S0 to S32) for the Jingbian site in northern China (Ding et al., 2005). Jingbian is one of multiple sites with long loess sections spread over the loess plateau (e.g. Ding et al., 2002; Hao et al., 2012). High values of magnetic susceptibility indicate repeated episodes of weathering (soil formation), predominantly in interglacials with relative strong summer monsoon. In intercalated strata (units L1 to L33; accumulated during glacials) the proportion of coarser grains (grains $>63 \mu \mathrm{m}, \%$ dry weight) is a signal of progressive desertification in Central Asia. While the long loess record is portrayed as a continuous curve, chronometric investigations reveal individual sections such as Jingbian to contain resolvable hiatuses (e.g. Stevens et al., 2018). For now, the magnetic and grain-size data has remained plotted on the Chinese Loess Particle Time Scale (Ding et al., 2002). Future versions of the chart may well contain time scale updates, re-synced to the speleothem, paleomagnetic, Antarctic ice core and oceanic studies mentioned above. Alternating loess-palaeosol sequence accumulation throughout NE China coincides with the begin of the Pleistocene and buries the more intensively weathered Pliocene 'Red Clay' Formation (An Zhisheng et al., 1990).

The Siberian Lake Baikal sediments provide a bioproductivity record from the heart of the world's largest landmass, an area of extreme continental climate. High concentrations of biogenic silica indicate high aquatic production during interglacials (i.e., lake diatom blooms during ice-free summer seasons), mimicked in other proxy-records from the lake (e.g. Prokopenko et al., 2010, exemplified for MIS 11). The composite biogenic silica record from cores BDP-96-1, -96-2 and -98 is plotted on an astronomically tuned age-scale (above 1.2 Ma: Prokopenko et al., 2006; below 1.2 Ma: Prokopenko \& Khursevich, 2010). 


\section{Regional stage/substage divisions}

The continuous sequences, above, provide the comparison for a selection of continental and shallow marine stage-sequences from around the world reconstructed from discontinuous sedimentary successions. Solid horizontal lines on the plots indicate observed boundaries, where no lines separate stages, additional events may potentially be recognised in the future.

The NW European stages are taken from Zagwijn (1992) and De Jong (1988). The British stages are taken from Mitchell et al. (1973); Gibbard et al. (1991) and Bowen (1999). The Russian Plain stages division scheme has been replaced. Where past version of the chart drew upon the Stratigraphy of the USSR: Quaternary System (1982, 1984), Krasnenkov et al. (1997) and Shik et al. (2002), the current scheme is based on Shik (2014) and Shik et al. (2015), translated by A.K. Markova (pers. comm.). A scheme for the Ukrainian Loess Plain is also included, based on Van Kolfschoten \& Gerasimenko (2006), N. Gerasimenko (pers. comm). Of similar length as the 'Standard Stages' in the marine scheme for the Mediterranean from the southern Italy sites, the Russian-Ukrainian Plain schemes recognise the Neopleistocene equivalent to Middle and Late Pleistocene subseries, and the Eopleistocene equivalent to the Calabrian. Following the redefinition of the base of the Lower Pleistocene in 2009, the term Paleopleistocene was introduced (Tesakov et al., 2015) for the equivalent of the Gelasian.

The North American column includes a provisional lettering scheme for pre-Illinoian glacial stages by Richmond (unpublished). Reassessing the chart contents for the current publication, the scheme was checked against Roy et al. (2004), Barendregt \& Duk-Rodkin (2004) and Jennings et al. (2007) reviews of that continent's record, which for the Laurentide ice sheet recognise Gauss/Matuyama glaciation (presumably equivalent to the pre-Illinoian K); early Matuyama glaciations (?H-J); late Matuyama glaciations (?F,G) and Brunhes glaciations (?A-E) at markedly increasing size — besides simultaneous developments of Cordilleran glaciation. The New Zealand stages are taken from Pillans (1991) and Beu (2004).

\section{Higher-resolution inset correlation table for the last 50,000 years}

More detailed chronologies and division schemes than could be shown in Figure 1, exist for the Late Pleistocene and Holocene, allowing to define and label subdivisions of millennial duration. As a highresolution inset supplementing the main chart, Figure 2 shows these for the last 50,000 years, with focus on the North Atlantic, Greenland and NW Europe.

Labels along the bottom of the inset table (Fig. 2) highlight what geological property and/or research method underpins the time control. Panels on the left copy schemes and records from the main one (the benthic record of core MD95-2042, is part of the LR04 benthic stack featured in Fig. 1), while panels to the right are replacements (e.g. Greenland ice core data, instead of Antarctic). The inset table covers 
the last 50,000 years because that is the end point of the IntCal13 and Marine13 radiocarbon calibration data set (Fig. 2 far right; Reimer et al., 2013), that are the standards for calibrating ${ }^{14} \mathrm{C}$ dates obtained from terrestrial and marine surface water environments respectively. This is also quite close to the analytical limit of measuring radiocarbon activity against 'dead carbon' backgrounds.

Of the records featured in Figure 2, the IntCal13 calibration standard (based on tree ring annual layers up to $13.9 \mathrm{ka}$, other constructs for 13.9-50 ka) and annual layer counts on multi-proxy Greenland ice core data (Rasmussen et al. 2014) deliver high-accuracy chronometry and hence offering high-accuracy correlation targets events in other high-resolution records, with less accurate native chronometry. To help this, for the last glacial part of the Greenland record, a numbered division into stadials and interstadials (GS respectively GI; also known has Dansgaerd-Oeschger events) have been introduced (Rasmussen et al., 2014). The shown marine record examples (benthic record from core MD95-2042, Shackleton et al., 2003; Heinrich event beds, Voeckler \& de Abreu, 2011) stand example for such correlation exercises (making use of planktonic isotope signals in addition).

\section{Correlation resolution}

The main chart (Fig. 1) purposely uses a linear time scale to show the glacial-interglacial cyclicity that characterises the Quaternary as a whole. The records from the deep ocean floor and the Antarctic ice sheet (globally integrating signals) and from the Asian land mass interior (the world's most continental region) are plotted at native resolution to show graphically the climatic variation between and within the glacial-interglacial cycles, but not to read ages of the graph at that resolution. The original publications of these records are referred to for this purpose, with the caveat that since original record publication, age-depth models may have been updated. Where such revisions are known to the compilers, these have propagated into updated versions of the chart, and we refer to the paper with the ages used. In most cases, at native resolution (i.e. in the form in which the dataset was shown in the original publication and shared as dataset) is millennial, but the absolute age accuracy for tie-points in the records is in the order of 4-5,000 year.

Aligning the division scheme to plots of selected key records at their linear time axis, serves firstly to show the difference in durations of subsequent divisions. It also puts focus on the accuracy at which unit boundaries could be pin-pointed, on which we here make some remarks. Hitherto, the dating of the base of the last interglacial Eemian regional Stage in NW Europe (defined biostratigraphically) serves as the example. Close inspection of the chart will show the reader that this lags the start of Marine Isotope Stage 5 (MIS 5) from the deep-ocean record by a few thousand years (Sanchez-Goñi et al., 1999; Shackleton et al., 2003: c.126 vs. c.131 ka off Portugal; Sier et al., 2015: c.122 vs. c.130 ka further north in The Netherlands). Similarly, most clearly illustrated in Fig. 2, the beginning of the Holocene interglacial does not correspond to the onset of the current marine stage MIS 1 (see below; 
11.7 versus $14.5 \mathrm{ka}$ ) which it post-dates by 2-4000 years (see above). This serves to emphasise that there is not necessarily a direct correspondence between the stage boundaries in terrestrial and ocean environments and even between regions. The chronostratigraphic technical reason for this is that the divisions were recognised and defined on the basis of different criteria because the type of geological record and the paleoenvironmental proxy data in different settings. Deeper reasons underlying this are decisions on precisely how interglacial between glacial events should be defined, i.e. what should mark their beginning the interglacial phase and where they end (exemplified in Gibbard \& West, 2014). Choices on that have been different in proxy records studied on land (notably in mid-latitude vegetational successions) and those in the ocean (notably isotope chemostratigraphy).

In the Holocene Series and the Eemian regional Stage, the lag time between the mid-point of risings limbs of marine isotope plots (used to time the MIS terminations) and the onset of determined interglacial conditions from proxy records on land (marking beginnings of regionally defined Stages) is repeatedly chronometrically reconfirmed (Holocene: e.g. Rasmussen et al., 2006; Carlson \& Clark, 2012; Last Interglacial: e.g. Stirling et al. 1998; Sanchez-Goñi et al., 1999). Since the same principles and practices of chronostratigraphic recognition of interglacials between glacials and division of the marine isotope records are also applied to the older Pleistocene cycles, one would regard similar millennial-scale lags to exist and be of the same broad time duration as the accuracy at which specific events seen in the record tend to have been dated. This signals the resolution limit that a Quaternary correlation chart and correlation methods in general currently reach.

Furthermore, the diachroneity amongst chronostratigraphic boundaries from different settings, is also of the same broad duration as the phase lag observed between 'Milankovitch' orbital forcing of the climatic cycles (Laskar et al., 1993) and the oceanic oxygen-isotope registered signal of global climatic response. This is a result of the latency and hysteresis of the Northern Hemisphere ice sheets to accumulate ice when $65^{\circ} \mathrm{N}$ summer solar insolation drops and to melt when it rises (Imbrie \& Imbrie, 1980). This is a key parameter when astronomically tuning the age of repeated climatic oscillations seen in records generated for the longer Quaternary, the Neogene and beyond (Lourens et al., 1997). Lisiecki \& Raymo (2005) in their tuning of the LR04 stacked oceanic record, for obliquity forcing show the phase lag in the benthic oxygen isotope signal to be about 6,800 years in the Middle Pleistocene (with its $100 \mathrm{ka}$ glacial cycles and large ice sheets), whilst it is shorter in the Early Pleistocene and Pliocene (c. 3,400 years). About 1,000 years of these lags can be considered ocean response time, the remainder is Northern Hemisphere ice-sheet latency. Regional climate signals recorded in the vicinity of large ice masses can lag showing warming a few millennia longer than the ocean recorded mean global signal. 
In summary, the state of art of chronometric accuracy, understanding of response diachroneity and the practice of astronomical tuning combined, for the rest of the Pleistocene limit the accuracy at which chronostratigraphic correlation approaches currently operate to 3-5,000 years (0.003-5 Ma) in the best resolved records (including those shown in the chart). That value is very similar to the graphic limit at which one can read the time axis and visually compare event and boundary positions in the main chart (Fig. 1). Those who trace the references to the records illustrated and download original data files will find that the precision and dating accuracy of individual records is higher (especially close to chronometric tie-points used to establish down-record ages), but that accuracy is lost for interpolated ages between, when aligning independent records, and when matching regional stratigraphic unit boundaries over great distance to events in long records. The chart reading accuracy of 3-5,000 years thus applies to correlating events in the best resolved records displayed next to each other, and/or equating beds and event defining the basal boundaries of units in regional chronostratigraphical schemes. This accuracy limit has only loosely been estimated here and is meant to apply to the part of the chart below the Last Glacial cycle.

For the Late Pleistocene and Holocene, age-control accuracy nowadays is (sub)centennial owing to annual layer counting and radiocarbon dating (e.g. Rasmussen et al., 2006; Van der Plicht \& Hogg, 2006), far exceeding what can be graphically plotted in a 2.7 Ma chart with linear scale (for which reason we included Fig. 2). This paper is otherwise not exhaustive in documenting correlation resolution within the Late Pleistocene and Holocene. Papers by Rasmussen et al. (2006: Greenland ice core record), Reimer et al. (2013: IntCal13 and Marine13 radiocarbon age calibration data) provide accuracy target standards, that would be entry points for evaluating that. Event case evaluations performed to define the Holocene subseries (Walker et al. 2012, 2018) stand example for it, as does work on the timing of Heinrich events (event beds rich in ice rafter debris (IRD) at mid latitude in the North Atlantic; Voelker \& de Abreu, 2011) in relation to benthic and planktonic marine oxygen isotope geochemistry, and the annually layered Greenland ice core record (e.g.'H0' IRD bed timing within the Younger Dryas / GS-1; 'H4' IRD bed timing within GS-9). The Greenland ice core record and division schemes extend to the lower half of the Late Pleistocene, reaching the Last Interglacial (Rasmussen et al., 2014). Further high-resolution schemes exist from Asian regions sensitive to variations in monsoon-strength registering speleothem composite records (Wang et al., 2008; Cheng et al., 2009). The various high-resolution chronometric records for the youngest few cycles also support (if not drove) the age-depth model of the upper part of the Antarctic ice core records featured in Fig. 1.

\section{Discussion and Conclusion}

The sections above document and reference the contents of the chart and provide some background on the current level of understanding of the strongly climatic-oscillation sensitive geological records 
during the Quaternary around the world. Through the text the current use of the chronostratigraphic units, schemes and concepts in conjunction with other geological techniques and stratigraphic practices is also mentioned. The chart depicts overarching global schemes for labelling sediment sequences to named time periods, as well as regional ones. Besides such schemes, the chart also depicts long geological records of reasonably high and constant resolution, showing climatic variability and character as it developed over the Quaternary System/Period.

The basic practical use of the table is to have it at hand to check terms and references for regions that one is not familiar with (reference chart), to give one's audience an overview of diversity and communality in the global record of the last $2.7 \mathrm{Ma}$. In this description of the chart, the authors aimed to summarise also the advanced scientific use of the schemes and records brought together on the chart. It is common practice to correlate between schemes, between long records, and between each other when interpreting regional and global Quaternary records, which is practical to an accuracy limit that is similar to the graphic resolution of the $2.7 \mathrm{Ma}$ chart as a whole (Fig. 1). The outcomes of the many correlative studies (by many diverse groups, an arbitrary selection being cited here) made it possible to compile the main chart, at the given resolution.

Since its conception, the chart description has included a status overview on internationally formalisation of the chronostratigraphic subdivisions in the Quaternary in the internationally recognised hierarchy of Series, Subseries, Stages and GSSPs (e.g. Pillans \& Gibbard, 2012; Head \& Gibbard, 2015), to present the youngest part of the Geological Time Scale compatible with remaining International Chronostratigraphic Chart. In the Early and Middle Pleistocene, the use of chronostratigraphic units and the approach to defining their boundaries (seeking marine sections exposed on land in which to define formal GSSP boundaries) has been closely comparable to the approach adopted for the Neogene. This is quite different for the Holocene where dating resolution is considerably higher than in the previous $2.7 \mathrm{Ma}$ (where annually laminated ice-cores and speleothems where formal boundaries have been identified). The Late Pleistocene division is yet to be formally defined, which is dependent on the identification of an agreed base for the Last Interglacial. Seeking a GSSP for this interval is an important priority since clarity over the initiation of the Last Interglacial holds information for (1) repetitiveness of earlier glacial-interglacial cyclicity and (2) analogue global climate and ice volume states in the present and near future. When one wants to substantiate the arguments for drawing the latter analogies, it is good to have the response variability between subsequent glacial-interglacial transitions and timing of arrival of climax conditions assessed. This is also what is required to improve age attributions to events within past glacial-interglacial cycles as part of quantifying earth-system functioning, as well as for testing and improving the accuracy of chronostratigraphic correlations communicated for the last $2.7 \mathrm{Ma}$, beyond present chart resolution. 
Finally, this latest version of the chart and documentation represent, as far as possible, the current state of knowledge at the time of writing. However, the production of the chart is an on-going process, it is therefore necessary to continually update the correlation table as new evidence emerges.

\section{Acknowledgements}

We thank Lewis Owen (University of Cincinnati, U.S.A.; interim president of INQUA's SACCOM commission) and Martin Head (Brock University, Canada; chair of IUGS-ICS' SQS subcommission) for their careful reviews of the manuscript text and chart. Personal communication with many colleagues (cited in the text) on their data and schemes included in the chart was greatly appreciated, both when compiling this version (J.E.T. Channell, A.K. Markova, N. Gerasimenko) and many others when doing previous versions.

\section{References}

Agassiz, L. 1847 Système glaciaire ou recherches sur les glaciers, leur mécanisme, leur ancienne extension et le rôle qu'ils ont joué dans l'histoire de la terre. Victor Masson.

Aguirre, E. \& Pasini, G. 1985 The Pliocene-Pleistocene boundary. Episodes 8, 116-120.

An Zhisheng, Lui Tungsheng, Porter, S.C., Kukla, G., Wu Xihao \& Hua Yingming 1990 The long-term paleomonsoon variation record by the loess-paleosol sequence in central China. Quaternary International 7/8, 91-95.

Bartoli, G., Sarnthein, M., Weinelt, M., Erlenkeuser, H., Garbe-Schönberg, D., \& Lea, D. 2005 Final closure of Panama and the onset of northern hemisphere glaciation, Earth and Planetary Science Letters 237, 33-44.

Barlow, N.L.M., McClymont, E.L., Whitehouse, P.L., Stokes, C.R., Jamieson, S.S.R., Woodroffe, S.A., Bentley, M.J., Callard, S.L., Ó Cofaigh, C., Evans, D.J.A. \& Horrocks, J.R. 2018 Lack of evidence for a substantial sea-level fluctuation within the Last Interglacial. Nature Geoscience 11, 627-634.

Berggren, W.S., Hilgen, F.J., Langereis, C.G., Kent, D.V., Obradovich, J.D., Raffi, I., Raymo, M.E. \& Shackleton, N.J. 1995 Late Neogene chronology: new perspectives in high-resolution stratigraphy. Geological Society of America Bulletin 107, 1272-1287.

Beu, A.G., 2004. Marine mollusca of oxygen isotope stages of the last 2 million years in New Zealand. Part 1: Revised generic positions and recognition of warm-water and cool-water immigrants. Journal of the Royal Society of New Zealand, 34: 111-265.

Bowen, D.Q. 1999. A revised correlation of the Quaternary deposits in the British Isles. Geological Society Special Report no.23.

Bowen, D.Q. \& Gibbard, P.L. 2007 The Quaternary is here to stay. Journal of Quaternary Science 22, 3-8.

Broecker, W.S. \& Donk, J. 1970 Insolation changes, ice volumes, and the O18 record in deep-sea cores. Reviews of Geophysics 8, 169-198.

Channell, J.E.T., Hodell, D.A., \& Lehman, B. 2009. Relative geomagnetic paleointensity and $\delta^{18} \mathrm{O}$ at ODP Site 983 (Gardar Drift, North Atlantic) since 350 ka. Earth and Planetary Science Letters 153, 103-118.

Channell, J.E.T., Xuan, C., Hodell, D.A., 2009. Stacking paleointensity and oxygen isotope data for the last 1.5 Myr (PISO-1500). Earth and Planetary Science Letters 283, 14-23 
Channell, J.E.T., Hodell, D.A. \& Curtis, J.H., 2016 Relative paleointensity (RPI) and oxygen isotope stratigraphy at IODP Site U1308: North Atlantic RPI stack for 1.2-2.2 Ma (NARPI-2200) and age of the Olduvai Subchron. Quaternary Science Reviews 131, 1-19.

Cita, M.B., 2008 Summary of Italian marine stages of the Quaternary. Episodes 31, 251-254.

Cita, M.B., Capraro, L., Ciaranfi, N., Di Stephano, E., Marino, M., Rio, D., Sprovieri, R. \& Vai, G.B., 2006 Calabrian and Ionian: A proposal for the definition of Mediterranean stages for the Lower and Middle Pleistocene. Episodes 29, 107-113.

Cita, M.B. \& Pillans, B., 2010 Global stages, regional stages or no stages in the Plio/Pleistocene: Quaternary International 219, 6-15.

Cheng, H., Edwards, R.L., Broecker, W.S., Denton, G.H., Kong, X., Wang, Y., Zhang, R., \& Wang, X. 2009 Ice Age Terminations. Science 326, 248-251.

Cohen, K.M. \& Gibbard, P.L. 2010. Global chronostratigraphical correlation table for the last 2.7 million years v.2010. Subcommission on Quaternary Stratigraphy, International Commission on Stratigraphy: Cambridge.

Cohen, K.M. \& Gibbard, P.L. 2016. Global chronostratigraphical correlation table for the last 2.7 million years v.2016. Subcommission on Quaternary Stratigraphy, International Commission on Stratigraphy: Cambridge / $35^{\text {th }}$ International Geological Congress: Cape Town.

Cohen, K.M., Finney, S.C., Gibbard, P.L. \& Fan, J.X., 2013. The ICS international chronostratigraphic chart. Episodes 36, 199-204.

Ding, Z.L., Derbyshire, E., Yang, S.L., Yu, Z.W., Ziong, S.F. \& Liu, T.S. 2002 Stacked 2.6-Ma grainsize record from the Chinese loess based on five sections and correlation with the deep-sea $\delta^{18} \mathrm{O}$ record. Paleooceanography 17, 1033, doi:10.1029/2001PA000725.

Ding, Z.L., Derbyshire, E., Yang, S.L., Sun, J.M. \& Liu, T.S. 2005 Stepwise expansion of desert environment across northern China in the past 3.5 Ma and implications for monsoon evolution. Earth and Planetary Science Letters, 237, 45-55.

Dutton, A. \& Lambeck, K. 2012 Ice Volume and Sea Level During the Last Interglacial. Science, 337, $216-219$.

Dutton, A., Carlson, A.E., Long, A.J., Milne, G.A., Clark, P.U., DeConto, R., Horton, B.P., Rahmstorf, S. and Raymo, M.E., 2015. Sea-level rise due to polar ice-sheet mass loss during past warm periods. Science, 349(6244), p.aaa4019.

De Jong, J. 1988: Climatic variability during the past three million years, as indicated by vegetational evolution in northwest Europe and with emphasis on data from The Netherlands. Philosophical Transactions of the Royal Society of London B 318, 603-617.

EPICA members 2004 Eight glacial cycles from an Antarctic ice core. Nature 429, 623-628.

Gibbard, P.L. 2003. Definition of the Middle / Upper Pleistocene boundary. Global and Planetary Change 36, 201-208.

Gibbard, P.L, 2010. The newly-ratified definition of the Quaternary System/Period and redefinition of the Pleistocene Series/Epoch, and comparison of proposals advanced prior to formal ratification. Episodes, 33, $152-158$

Gibbard, P.L. \& Head, M.J. 2009a The definition of the Quaternary System/Period and the Pleistocene Series/Epoch. Quaternaire, 20, 125-133. 
Gibbard, P.L. \& Head, M.J. 2009b IUGS ratification of the Quaternary System/Period and the Pleistocene Series/Epoch with a base at 2.58 Ma. Quaternaire 20, 411-412.

Gibbard, P.L. \& West, R.G. 2014. The development of the stratigraphical division of the Quaternary as reflected in the activities of the Quaternary Research Association. In: Catt, J.A. \& Candy, I. (Eds.) History of the Quaternary Research Association. QRA, London, 173-188.

Gibbard, P.L., West, R.G. \& Zagwijn, W.H. (editors) 1991 Early and early Middle Pleistocene correlations in the southern North Sea Basin. Quaternary Science Reviews 10, 23-52.

Gibbard, P.L. Smith, A.G., Zalasiewicz, J.A., Barry, T.L., Cantrill, D., Coe, A.L., Cope, J.C.W., Gale, A.S., Gregory, F.J., Powell, J.H., Rawson, P.R., Stone, P. \& Waters, C.N. 2005 What status for the Quaternary? Boreas 34, 1-12.

Gibbard, P.L., Cohen, K.M., Boreham, S. \& Moscariello, A. 2004. Global chronostratigraphical correlation table for the last 2.7 million years. Subcommission on Quaternary Stratigraphy, International Commission on Stratigraphy: Cambridge.

Gibbard, P.L., Boreham, S., Cohen, K.M. \& Moscariello, A. 2005 Global chronostratigraphical correlation table for the last 2.7 million years. Boreas 34 (1) (inclusion).

Gibbard, P.L. \& Cohen, K.M. 2008. Global chronostratigraphical correlation table for the last 2.7 million years. Episodes 31, 243-247.

Gibbard, P.L. \& Head, M.J. 2010 The newly-ratified definition of the Quaternary System/Period and redefinition of the Pleistocene Series/Epoch, and comparison of proposals advanced prior to formal ratification.Episodes 33 152-158,Gibbard, P.L., Head, M.J. \& Walker, M.J. 2010. Formal ratification of the Quaternary System/Period and the Pleistocene Series/Epoch with a base at 2.58 Ma. Journal of Quaternary Science 25, 96-102.

Hao, Q., Wang, L., Oldfield, F., Peng, S., Qin, L., Song, Y., Xu, B., Qiao, Y., Bloemendal, J. \& Guo, Z., 2012. Delayed build-up of Arctic ice sheets during 400,000-year minima in insolation variability. Nature 490, 393396.

Head, M.J. \& Gibbard, P.L., 2005. Early-Middle Pleistocene transitions: an overview and recommendation for the defining boundary. In: M.J. Head and P.L. Gibbard (Editors), Early-Middle Pleistocene transitions: the land-ocean evidence. Geological Society of London, Special Publication 247: 1-18.

Head, M.J. \& Gibbard, P.L. 2015. Formal subdivision of the Quaternary System/Period: past, present, and future. Quaternary International 383, 1-32.

Head, M.J., Gibbard, P.L. \& Salvador, A. 2008a The Quaternary: its character and definition. Episodes 31, 234238.

Head, M.J., Pillans, B. \& Farquhar, S.A. 2008b The Early-Middle Pleistocene transition: characterization and a proposed guide for the defining boundary. Episodes 31, 234-238.

Hennissen, J.A.I., Head, M.J., De Schepper, S., \& Groeneveld, J. 2014 Palynological evidence for a southward shift of the North Atlantic Current at $\sim 2.6 \mathrm{Ma}$ during the intensification of late Cenozoic Northern Hemisphere glaciation. Paleoceanography 28, PA002543.

Hennissen, J.A.I., Head, M.J., De Schepper, S., \& Groeneveld, J., 2015 Increased seasonality during the intensification of Northern Hemisphere glaciation at the Pliocene-Pleistocene boundary 2.6 Ma. Quaternary 
Science Reviews 129, 321-332.Hoek, W.Z. 2008 The Last Glacial-Interglacial Transition. Episodes 31, 226229.

Hughes, P.D. \& Gibbard, P.L. 2015. A stratigraphical basis for the Last Glacial Maximum (LGM). Quaternary International 383, 174-185.Imbrie, J. \& Imbrie, J.Z. 1980 Modeling the climatic response to orbital variations. Science 207, 943-953.Jennings, C.E., Aber, J.S., Balco, G., Barendregt, R., Bierman, P.R., Rovey, C.W., Thorleifson, L.H., Mason, J.A. and Elias, S.A., 2007. Mid-Quaternary in North America. Encyclopedia of Quaternary Sciences. Amsterdam: Elsevier, 1044-1051.

Jouzel, J., Masson-Delmotte, V., Cattani, O., Dreyfus, G., Falourd, S., Hoffmann, G., Nouet, J., Barnola, J. M., Chappellaz, J., Fischer, H., Gallet, J. C., Johnsen, S., Leuenberger, M., Loulergue, L., Luethi, D., Oerter, H., Parrenin, F., Raisbeck, G., Raynaud, D., Schwander, J., Spahni, R., Souchez, R., Selmo, E., Schilt, A., Steffensen, J. P., Stenni, B., Stauffer, B., Stocker, T., Tison, J.-L., Werner, M. \& Wolff, E. W. (2007): Orbital and millennial Antarctic climate variability over the last 800000 years. Science 317, 793-796

Krasnenkov R.V., Iossifova Yu.I. \& Semenov V.V. 1997 The Upper Don drainage basin - an important stratoregion for climatic stratigraphy of the early Middle Pleistocene (the early Neopleistocene) of Russia. Quaternary geology and paleogeography of Russia. Moscow. Geosynthos 82-96. (Russian; abstract in English).

Kukla, G.J., Bender, M.L., de Beaulieu, J.L., Bond, G., Broecker, W.S., Cleveringa, P., Gavin, J.E., Herbert, T.D., Imbrie, J., Jouzel, J., Keigwin, L.D., Knudsen, K.-L., McManus, J.F., Merkt, J., Muhs, D.R., Müller, H., Poore, R.Z., Porter, S.C., Seret, G., Shackleton, N.J., Turner, C., Tzedakis, P.C. \& Winograd, I.J. 2002 Last interglacial climates. Quaternary Research 58, 2-13.

Laj, C. \& Channell, J.E.T. 2007 Geomagnetic excursions. Chapter 10 in: Kono, M. (Ed.) Treatise on Geophysics: Volume 5, Geomagnetism. Elsevier, Amsterdam, 373-416.

Lambeck, K., Purcell,, A., Funder, S., Kjær, K.H., Larsen, E. \& Moller, P. 2006 Constraints on the Late Saalian to early Middle Weichselian ice sheet of Eurasia from field data and rebound modelling. Boreas, 35, 539-575.

Laskar, J., Joutel, F. \& Boudin, F. 1993 Orbital, precessional, and insolation quantities for the Earth from -20 MYR to +10 MYR, Astronomy and Astrophysics 270, 522-533.

Litt, T., Brauer, A., Goslar, T., Merkt, K., Balaga, K., Müller, H., Ralska-Jasiewiczowa, M. Stebich, M. \& Negendank, J.F.W. 2001 Correlation and synchronisation of lateglacial continental sequences in northern central Europe based on annually laminated lacustrine sediments. Quaternary Science Reviews 20, 12331249.

Litt, T. \& Gibbard, P.L. 2008 A proposed Global Stratotype Section and Point (GSSP) for the base of the Upper (Late) Pleistocene Subseries (Quaternary System/Period). Episodes 31, 260-261.

Lisiecki, L.E. \& Raymo, M.E. 2005 A Plio-Pleistocene Stack of 57 Globally Distributed Benthic $\delta^{18}$ O Records. Paleoceanography 20, PA1003, 17 pp.

Lisiecki, L.E. 2014. Atlantic overturning responses to obliquity and precession over the last 3 Myr. Paleoceanography 29, 71-86.

Lourens, L.J. 2004 Revised tuning of Ocean Drilling Program Site 964 and KC01B (Mediterranean) and implications for the $\delta^{18} \mathrm{O}$, tephra, calcareous nannofossil, and geomagnetic reversal chronologies of the past 1.1 Myr. Paleoceanography 19, PA3010.

Lourens, L.J. 2008 On the Neogene-Quaternary debate. Episodes 31, 239-242. 
Lourens, L.J., Antonarakou, A., Hilgen, F.J., Van Hoof, A.A.M., Vergnaud-Grazzini, C. and Zachariasse, W.J., 1996. Evaluation of the Plio-Pleistocene astronomical timescale. Paleoceanography and Paleoclimatology $11,391-413$.

Long, A.J., Barlow, N.L.M., Busschers, F.S., Cohen, K.M., Gehrels, W.R. and Wake, L.M. 2015 Near-field sealevel variability in northwest Europe and ice sheet stability during the last interglacial. Quaternary Science Reviews 126, 26-40.

Lunt, D. J., Valdes, P. J., Haywood, A. M., \& Rutt, I. C.: Closure of the Panama Seaway during the Pliocene: implications for climate and Northern Hemisphere glaciation, Climate Dynamics 30, 1-18.

Martinson, D.G., Pisias, N.G., Hays, J.D., Imbrie, J., Moore, T.C. \& Shackleton, N.J., 1987 Age dating and the orbital theory of the ice ages: development of a high-resolution 0 to 300,000-year chronostratigraphy. Quaternary research 27, 1-29.

Medina-Elizalde, M. 2013 A global compilation of coral sea-level benchmarks: Implications and new challenges. Earth and Planetary Science Letters 362, 310-318.

Mitchell, G.F., Penny, L.F., Shotton, F.W., West R.G. 1973 A Correlation of Quaternary deposits in the British Isles. Geological Society of London Special Report 4, 99 pp.

Ogg, J. \& Pillans, B. 2008 Establishing Quaternary as a formal International Period/System, Episodes Vol. 31, 230-233.

Partridge, T.C. 1997 Reassessment of the position of the Plio-Pleistocene boundary: is there a case for lowering it to the Gauss-Matuyama Palaeomagnetic reversal? Quaternary International 40, 5-10.

Penck, A. \& Brückner, E., 1909. Die alpen im Eiszeitalter. Tauchnitz, Switzerland.Petit, J.R., Jouzel, J., Raynaud, D., Barkov, N.I., Barnola, J.-M., Basile, I., Bender, M., Chappellaz, J., Davis, M., Delayque, G., Delmotte, M., Kotlyakov, V.M., Legrand, M., Lipenkov, V.Y., Lorius, C., Pépin, L., Ritz, C., Saltzman, E. \& Stievenard, M. 1999 Climate and atmospheric history of the past 420,000 years from the Vostok ice core, Antarctica. Nature 399, 429-436Partridge, T.C. (ed.) 1997a The Plio-Pleistocene boundary. Quaternary International 40, 1-100.

Pillans, B. 1991 New Zealand Quaternary stratigraphy: an overview. Quaternary Science Reviews 10, 405-418.

Pillans, B. \& Naish, T. 2004 Defining the Quaternary. Quaternary Science Reviews 23, 2271-2282.

Pillans, B. \& Gibbard, P.L. 2012. The Quaternary Period. In: Gradstein, F.M., Ogg, J.G., Schmitz, M., Ogg, G. (eds.) The Geologic Time Scale 2012. Elsevier, 979-1010.

Prokopenko, A.A., Hinnov, L.A., Williams, D.F., Kuzmin, M.I. 2006 Orbital forcing of continental climate during the Pleistocene: a complete astronomically-tuned climatic record from Lake Baikal, SE Siberia. Quaternary Science Reviews 25, 3431-3457.

Prokopenko, A.A., Bezrukova, E.V., Khursevich, G.K., Solotchinea, E.P., Kuzmin, M.I. \& Tarasov, P.E. 2010 Climate in continental interior Asia during the longest interglacial of the past 500000 years: the new MIS 11 records from Lake Baikal, SE Siberia. Climate of the Past, 6, 31-48.

Prokopenko, A.A. \& Khursevich, G.K. 2010 Plio-Pleistocene transition in the continental record from Lake Baikal: Diatom biostratigraphy and age model. Quaternary International, 219, 26-36.

Railsback, L.B., Gibbard, P.L., Head, M.J., Voarintsoa, N.R.G. and Toucanne, S., 2015. An optimized scheme of lettered marine isotope substages for the last 1.0 million years, and the climatostratigraphic nature of isotope stages and substages. Quaternary Science Reviews 111, 94-106. 
Rasmussen, S. O., Andersen, K.K., Scensson, A.M., Steffensen, J.P., Vinther, B.M., Clausen, H.B., SiggaardAndersen, M.-L., Johnsen, S.J., Larsen, L.B., Dahl-Jensen, D., Bigler, M., Röthlisberger, R. Fischer, H., Goto-Azuma, K., Hansson, M.E. \& Ruth, U. 2006. A new Greenland ice core chronology for the last glacial termination, Journal of Geophysical Research 111. D06102.

Rasmussen, S.O., Bigler, M., Blockley, S.P., Blunier, T., Buchardt, S.L., Clausen, H.B., Cvijanovic, I., DahlJensen, D., Johnsen, S.J., Fischer, H. \& Gkinis, V., 2014. A stratigraphic framework for abrupt climatic changes during the Last Glacial period based on three synchronized Greenland ice-core records: refining and extending the INTIMATE event stratigraphy. Quaternary Science Reviews 106, 14-28.

Reimer, P.J., Bard, E., Bayliss, A., Beck, J.W., Blackwell, P.G., Ramsey, C.B., Buck, C.E., Cheng, H., Edwards, R.L., Friedrich, M. \& Grootes, P.M., 2013 IntCal13 and Marine13 radiocarbon age calibration curves 050,000 years cal BP. Radiocarbon, 55, 1869-1887.

Richmond, G.M. 1996 The INQUA-approved provisional Lower-Middle Pleistocene boundary. In: Turner C. The early middle Pleistocene in Europe. Balkema: Rotterdam, 319-326.

Rio, D., Sprovieri, R., \& Di Stefano, E. 1994 The Gelasian Stage: a proposal of a new chronostratigraphic unit of the Pliocene Series. Rivista Italiano di Paleontoloqia e Stratigrafia 100, 103-124.

Rio, D., Sprovieri, R., Castradori, D., \& Di Stefano, E. 1998 The Gelasian Stage (Upper Pliocene): A new unit of the global standard chronostratigraphic scale: Episodes 91, 82-87.

Roy, M., Clark, P.U., Barendregt, R.W., Glasmann, J.R. \& Enkin, R.J. 2004 Glacial stratigraphy and paleomagnetism of late Cenozoic deposits of the north-central United States. Geological Society of America Bulletin 116, 30-41.

Sarnthein, M., Bartoli, G., Prange, M., Schmittner, A., Schneider, B., Weinelt, M., Andersen, N. \& GarbeSchönberg, D. 2009 Mid-Pliocene shifts in ocean overturning circulation and the onset of Quaternary-style climates. Climate of the Past 5, 269-283.

Shackleton, N.J. (1969). The last interglacial in the marine and terrestrial record. Proceedings of the Royal Society London, Series B 174, 135-154.

Shackleton, N.J., Sánchez-Goñi, M.F., Pailler, D. \& Lancelot, Y. (2003). Marine Isotope Substage 5e and the Eemian Integlacial. Global and Planetary Change 36, 151-155.

Shik, S.M. 2014 A modern approach to the Neopleistocene stratigraphy and paleogeography of Central European Russia. Stratigraphy and Geological Correlation 22, 219-230. Translation of: Shik, S.M. 2014 Stratigrafiya. Geologicheskaya Korrelyatsiya 22, 108-120 (in Russian).

Shik, S.M., Borisov, B.A., \& Zarrina E.P. 2002 About the project of the interregional stratigraphic scheme of the Neopleistocene of East European Platform and improving regional stratigraphic schemes. The Third All Russian Meeting on Quaternary research. Abstracts. Geological Institute RAN - Smolensky Pedagogical University. Smolensk. p. 125-129. (in Russian).

Shik, S.M., Tesakov, A.S., Agadjanian, A.K., Iosifova, Yu.I., Markova, A.K., Pisareva, V.V. \& Semenov, V.V. 2015. A regional stratigraphical scheme of Eopleistocene and Gelasian (Paleopleistocene) of Central and Southern parts of European Russia". Bulletin of Regional Intra-Institutional Commission of Central and South of Russian Plains 6, 97-107. (in Russian). 
Sier, M.J., Peeters, J., Dekkers, M.J., Parés, J.M., Chang, L., Busschers, F.S., Cohen, K.M., Wallinga, J., Bunnik, F.P. \& Roebroeks, W., 2015. The Blake Event recorded near the Eemian type locality - A diachronic onset of the Eemian in Europe. Quaternary Geochronology 28, 12-28.

Siddall, M., Rohling, E.J., Almogi-Labin, A., Hemleben, C., Meischner, D., Schmelzer, I. \& Smeed, D.A. 2003 Sea-level fluctuations during the last glacial cycle. Nature 423, 853-858.

Suggate, R.P. 1965. The definition of "interglacial". The Journal of Geology 73, 619-626.

Stevens, T., Buylaert, J.P., Thiel, C., Újvári, G., Yi, S., Murray, A.S., Frechen, M. \& Lu, H. 2018 Ice-volumeforced erosion of the Chinese Loess Plateau global Quaternary stratotype site. Nature communications 9, 983995.

Stirling, C.H., Esat, T.M., Lambeck, K. \& McCulloch, M.T. 1998 Timing and duration of the Last Interglacial: evidence for a restricted interval of widespread coral reef growth. Earth and Planetary Science Letters, 160, 745-762.

Stuiver, M. \& Polach, H. 1977 Reporting of ${ }^{14} \mathrm{C}$ data Radiocarbon 19, 355-363.

Stratigraphy of the USSR: Quaternary System (1982) volume 1, Moscow. Nedra. 443 pp. (in Russian).

Stratigraphy of the USSR: Quaternary System (1984) volume 2. Moscow. Nedra. 556 pp. (in Russian).

Suc, J.P., Bertini, A., Leroy, S.A.G. \& Suballyova, D. 1997 Towards a lowering of the Pliocene/Pleistocene boundary to the Gauss/Matuyama Reversal. In: Partridge, T.C. 1997 (ed.) The Plio-Pleistocene boundary. Quaternary International 40, 37-42.

Suganuma, Y., Okada, M., Horie, K., Kaiden, H., Takehara, M., Senda, R., Kimura, J.I., Kawamura, K., Haneda, Y., Kazaoka, O. and Head, M.J. 2015 Age of Matuyama-Brunhes boundary constrained by U-Pb zircon dating of a widespread tephra. Geology 43, 491-494.

Tesakov, A.S., Shik S.M., Velichko, A.A., Gladenkov, Yu.B., Lavrushin, Yu, A. Yanina, T.A. 2015 Proposed changes in the stratigraphic structure of the Quaternary for the Genernal Stratigraphic Scale of Russia. Proceedings of the All-Russian Scientific Meeting "Stratigraphic and Paleogeographic Problems of the Neogene and Quaternary of Russia (New Materials and Methods)". GEOS, Moscow, 57-59.

van Couvering, J. 1997 Preface, the new Pleistocene. In: van Couvering, J. (ed.) The Pleistocene boundary and the beginning of the Quaternary. University Press: Cambridge. ii-xvii.

van der Plicht, J. \& Hogg, A. 2006 A note on reporting radiocarbon. Quaternary Geochronology 1, 237-240.

Vinther, B.M., Clausen, H.B., Johnsen, S.J., Rasmussen, S.O., Andersen, K.K., Buchardt, S.L., Dahl-Jensen, D., Seierstad, I.K., Siggard-Andersen, M.-L., Steffensen, J.P., Svensson, A. Olsen, J. \& Heinemeier, J. 2006 A synchronized dating of three Greenland ice cores throughout the Holocene. Journal of Geophysical Research, 111, D13102.

Voelker, A.H. \& de Abreu, L., 2011 A review of abrupt climate change events in the Northeastern Atlantic Ocean (Iberian Margin): Latitudinal, longitudinal, and vertical gradients. In: Rashid, H., Polyak, L. \& MosleyThompson, E. (Eds.) Understanding the Causes, mechanisms and extent of the Abrupt Climate Change. $A G U$ Geophysical Monograph 193, 15-37.Walker, M., Johnsen, S., Rasmussen, S.O., Steffensen, J.-P., Popp, T., Gibbard, P., Hoek, W., Lowe, J., Andrews, J., Björck, S., Cwynar, L., Hughen, K., Kershaw, P., Kromer, B., Litt, T., Lowe, D.J., Nakagawa, T., Newnham, R. \& Schwander, J. 2008 The Global Stratotype Section and Point (GSSP) for the base of the Holocene Series/Epoch (Quaternary System/Period) in the NGRIP ice core. Episodes 31, 264-267. 
Walker, M., Johnsen, S., Rasmussen, S.O., Popp, T., Steffensen, J.-P., Gibbard, P., Hoek, W., Lowe, J., Andrews, J., Bjorck, S., Cwynar, L.C., Hughen, K., Kershaw, P., Kromer, B., Litt, T., Lowe, D.J., Nakagawa, T., Newnham, R. and Schwander, J. 2009 Formal definition and dating of the GSSP (Global Stratotype Section and Point) for the base of the Holocene using the Greenland NGRIP ice core, and selected auxiliary records. Journal of Quaternary Science 24, 3-17.

Walker, M.J., Berkelhammer, M., Björck, S., Cwynar, L.C., Fisher, D.A., Long, A.J., Lowe, J.J., Newnham, R.M., Rasmussen, S.O. \& Weiss, H. 2012 Formal subdivision of the Holocene Series/Epoch: a Discussion Paper by a Working Group of INTIMATE (Integration of ice-core, marine and terrestrial records) and the Subcommission on Quaternary Stratigraphy (International Commission on Stratigraphy). Journal of Quaternary Science 27, pp. 649-659.

Walker, M., Head, M.H., Berklehammer, M., Bjorck, S., Cheng, H., Cwynar, L., Fisher, D., Gkinis, V., Long, A., Lowe, J. \& Newnham, R. 2018 Formal ratification of the subdivision of the Holocene Series/Epoch (Quaternary System/Period): two new Global Boundary Stratotype Sections and Points (GSSPs) and three new stages/subseries. Episodes 41: 213-223.

Wang, Y., H. Cheng, R.L. Edwards, X. Kong, X. Shao, S. Chen, J. Wu, X. Jiang, X. Wang, \& Z. An. 2008 Millennial- and orbital-scale changes in the East Asian monsoon over the past 224,000 years. Nature 451, 1090-1093.

Waters, C.N., Zalasiewicz, J., Summerhayes, C., Barnosky, A.D., Poirier, C., Gałuszka, A., Cearreta, A., Edgeworth, M., Ellis, E.C., Ellis, M. \& Jeandel, C. 2016 The Anthropocene is functionally and stratigraphically distinct from the Holocene. Science 351, aad2622.

Wolff, E.W. 2008 What is the "present"? Quaternary Science Reviews, 26, 3023-2024.

Zagwijn, W.H. 1992 The beginning of the Ice Age in Europe and its major subdivisions. Quaternary Science Reviews 11, 583-591.

Zalasiewicz, J., Waters, C.N., Summerhayes, C.P., Wolfe, A.P., Barnosky, A.D., Cearreta, A., Crutzen, P., Ellis, E., Fairchild, I.J., Gałuszka, A. \& Haff, P. 2017 The Working Group on the Anthropocene: Summary of evidence and interim recommendations. Anthropocene 19, 55-60.

\section{FIGURE CAPTIONS}

Fig. 1 Global chronostratigraphical correlation table for the last 2.7 million years, v. 2019. The figure is a compilation making extensive use of published data sets and schemes, all cited in the main text.

Fig. 2 Higher-resolution inset correlation table for the last 50,000 years. The figure is a compilation making extensive use of published data sets and schemes, all cited in the main text.

For Figure 1: we suggest placing the large figure as spread over three pages (even, odd, (skip), odd). The page holding the middle section than can be folded. The chart is prepared for such placement. 
Global chronostratigraphical correlation table for the last 2.7 million years v. 2019 QI-500

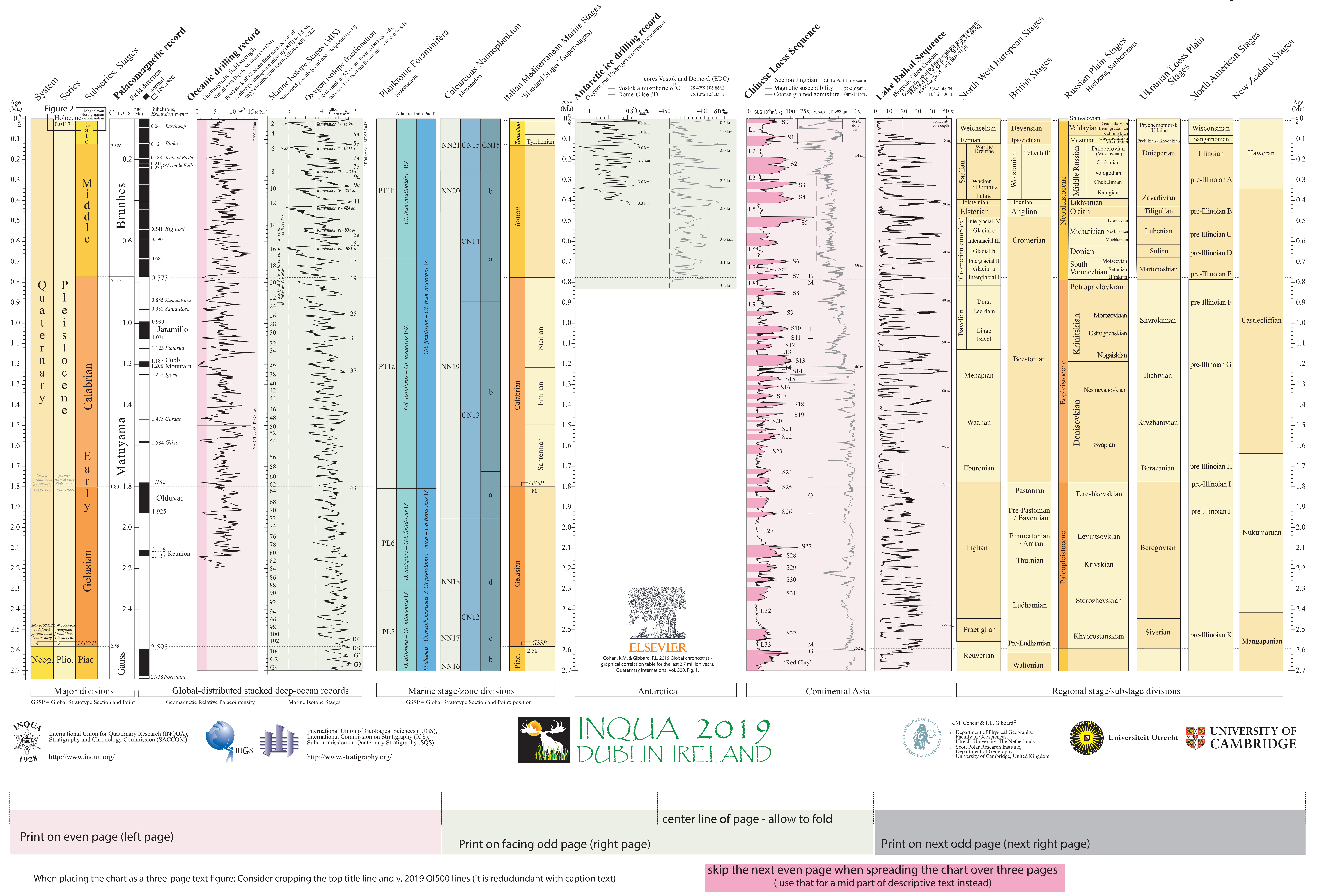




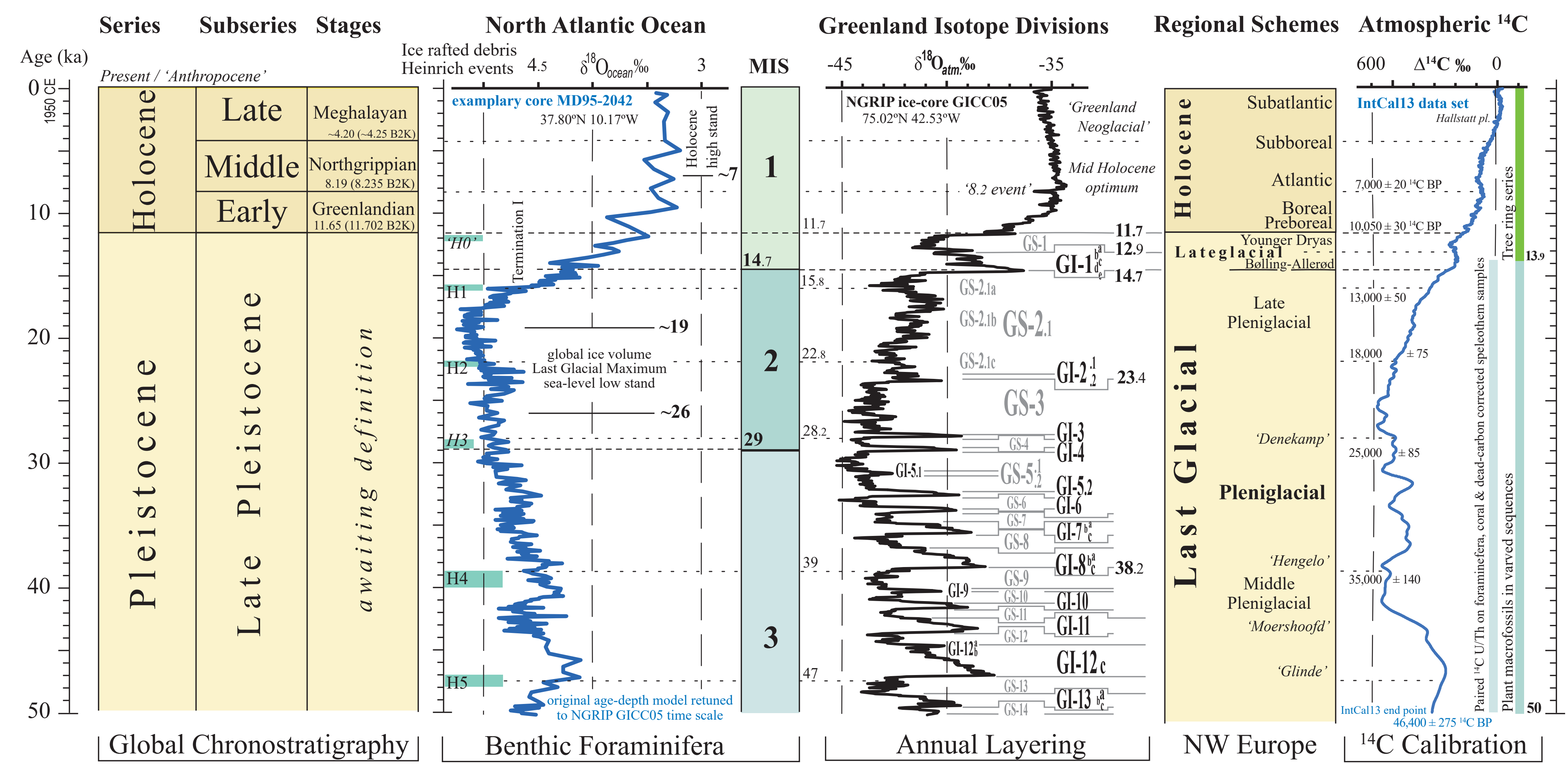

